\title{
A Randomized Controlled Trial of Ivermectin Monotherapy Versus Hydroxychloroquine, Ivermectin, and Azithromycin Combination Therapy in Covid-19 Patients in Nigeria
}

Olufemi Emmanuel Babalola ( $\nabla$ bablo57@gmail.com )

Bingham University, Karu https://orcid.org/0000-0001-7737-3831

Ndanusa Yahaya

Al Ummah Foundation, Abuja https://orcid.org/0000-0002-3708-2033

\section{A. Adesuyi Ajayi}

Baylor College of Medicine, Texas https://orcid.org/0000-0003-2036-7929

John Onimisi Ogedengbe

University of Abuja https://orcid.org/0000-0002-1559-1750

\section{Yunusa Thairu}

University of Abuja https://orcid.org/0000-0003-1941-8151

Ogu Omede

Federal Ministry of Health, Abuja https://orcid.org/0000-0001-6695-1405

\section{Research Article}

Keywords: COVID-19, ivermectin, hydroxychloroquine, azithromycin, Nigeria

Posted Date: October 1st, 2021

DOl: https://doi.org/10.21203/rs.3.rs-950352/v1

License: (c) (i) This work is licensed under a Creative Commons Attribution 4.0 International License.

Read Full License

Version of Record: A version of this preprint was published at Journal of Infectious Diseases and Epidemiology on October 31st, 2021. See the published version at https://doi.org/10.23937/2474$3658 / 1510233$. 


\section{Abstract}

The efficacy of ivermectin (IVM) against SARS-CoV-2 has been demonstrated in vitro, while several clinical studies suggest that it is efficacious and safe in reducing morbidity and mortality. Hydroxychloroquine HCQ, IVM and azithromycin AZM (HIA therapy) are being used in several low- and middle-income countries (LMICs) where more expensive medications such as remdesivir are out of reach. In this study, we set out to compare the efficacy of IVM monotherapy with HIA combination therapy.

Methods: This was a single-blind, randomized control trial of 2 parallel groups of COVID-19-positive Nigerians. Thirty patients received ivermectin $200 \mathrm{mcg} / \mathrm{kg}$ daily for five days, while 31 patients received $\mathrm{HIA}$ triple therapy. The viral cycle threshold (Ct) at pretreatment baseline and days 2, 514 and 21 were measured for the $\mathrm{E}$ - and $\mathrm{N}$-genes. $\mathrm{SPO}_{2}$ was assessed on a daily basis, while inflammatory markers erythrocyte sedimentation rate (ESR), C-reactive protein, and D-dimer and neutrophil/lymphocyte ratios (NLRs) were assessed at baseline and day 7. Clinical status was self-assessed daily on a Likert scale.

Results: Two-way repeated measures analysis of variance (RAMOVA) did not show any difference between the two groups. However, there was a significant time effect (improvement over time) for $\mathrm{SPO}_{2}$, $\mathrm{Ct} \mathrm{N-gene,} \mathrm{Ct} \mathrm{E-gene} \mathrm{and} \mathrm{clinical} \mathrm{status} \mathrm{in} \mathrm{both} \mathrm{groups} \mathrm{and} \mathrm{significant} \mathrm{reductions} \mathrm{in} \mathrm{inflammatory}$ markers by day 7. $(\mathrm{P}<0.0001)$.

Conclusions: AZT + HCQ may be a redundant adjuvant in COVID-19 therapy. Improvements noted are likely due in large part to ivermectin virucidal and anti-inflammatory actions.

\section{Introduction}

The WHO declared a COVID-19 pandemic caused by the SARS-CoV-2 virus on March 11, 2020, ${ }^{1}$. Since then, there have been global and massive disruptions in economic, transportation, social interaction, political, and health care delivery that have been unprecedented and unparalleled in recent human history. As of September 2021, more than 223 million people have been infected with more than 4.6 million mortality ${ }^{2}$. Robust measures, including vaccinations ${ }^{2}$, have become available to stem community transmission of the SARS-CoV-2 virus and especially the more contagious delta variant of SARS-CoV2 ${ }^{3}$. Recovery from the pandemic has, however, been slower than anticipated, owing to a combination of vaccine hesitancy in high-income countries and by resource limitation and vaccine insufficiency for the eligible population in low- and middle-income countries (LMICs). Other measures, in addition to public health modalities, including chemoprophylaxis and continued treatment of COVID 19 with a variety of repurposed drugs or their combinations, have therefore been employed. We have previously reported the beneficial effects of ivermectin in mild to moderate COVID-19 patients in a randomized controlled doubleblind, dose-response study ${ }^{4}$. We have also hypothesized the putative utility of an additive combination of ivermectin with a novel antiviral drug, molnupiravir ${ }^{5}$. After the publication of Gautret et al ${ }^{6}$ and Raoult et al $^{7}$, among others, doctors in many LMICs, including in Nigeria, prescribed a cocktail of ivermectin (IVM) combined with hydroxychloroquine (HCQ) and azithromycin (AZT) to treat early or mild COVID-19 
patients. Other studies have, however, suggested that HCQ is not as useful as postexposure prophylaxis and may be associated with ECG anomalies in a proportion of patients 8,9 .

Ivermectin has an in vitro IC50 for SARS-CoV-2 in Vero-SLAM cells of $2 .{ }^{4 \mu \mathrm{M} 10}$ and exerts inhibitory SARSCoV-2 effects by multifarious mechanisms, including blocking viral entry, inhibiting viral nuclear transport by importin alpha and beta, and inhibiting RNA-dependent RNA polymerase (RdRp). ${ }^{11}$

Chloroquine (CQ) and HCQ have IC50 values for the inhibition of SARS-CoV-2 in vitro of $42-56.8 \mu \mathrm{M}$ and 9.2-11.2 $\mu \mathrm{M}$, respectively ${ }^{12}$, but CQ does not inhibit SARS-CoV-2 infection in human lung cells ${ }^{13}$. The mechanisms of SARS-CoV-2 replication inhibition by CQ/HCQ include blockade of viral cell invasion via lipid rafts, interference with viral endocytosis, binding to ACE2 and viral spike protein, blockade of endosomal acidification, and sequestration of zinc ions that block SARS-CoV-2 RdRp. ${ }^{14}$

Azithromycin (AZT) is a macrolide antibiotic that has been reported to inhibit SARS-CoV-2 in vitro in Vero cells and in Caco-2 cells ${ }^{15}$. AZT has an IC50 of $2.1 \mu \mathrm{M}$, which is not dissimilar from the molar value for $\mathrm{IVM}^{16}$. It is a weak base and thus inhibits the acidic-dependent uncoating and endocytosis of the SARSCoV-2 virus. AZT binds the spike protein S, thereby reducing binding to the ACE2 receptor and limiting viral entry. The drug amplifies host antiviral defence through an increase in interferon (IFN) and inhibition of IL-6 production. ${ }^{17}$

There are reports of the additive or synergistic combination of AZT + HCQ in clinical trials in COVID $19,{ }^{18}$, even as other clinical trials, such as the RECOVERY Collaborative Group, showed no efficacy of HCQ in hospitalized COVID 19 patients. ${ }^{19}$ These disparate findings make it imperative to assess the additive or synergistic actions, if any, of the combinations of repurposed drugs used in COVID 19 treatment.

The purpose of the present study was to examine and compare the clinical, virological and antiinflammatory effects of ivermectin alone compared to ivermectin + HCQ + AZT triple therapy (HIA triple therapy or IVM+) in RT-PCR and SARS-CoV-2-positive patients with COVID-19 in a randomized controlled trial.

\section{Hypothesis}

Null hypothesis $\left(\mathrm{H}_{0}\right)$ : A combination of ivermectin and $\mathrm{HCQ}+\mathrm{A}$ is not more efficacious in the treatment of patients with virology-proven COVID-19 disease than ivermectin alone.

Alternative Hypothesis $\left(\mathrm{H}_{\mathrm{a}}\right)$ : A combination of ivermectin and HCQ is more efficacious in the treatment of patients with virology-proven COVID-19 disease.

\section{Materials And Methods}

Approval to carry out the research was obtained from the University of Abuja Health Research Ethics Committee. The study adhered to the tenets of the Declaration of Helsinki. 
(https://www.wma.net/policies-post/wma-declaration-of-helsinki-ethical-principles-for-medical-researchinvolving-human-subjects/)

Cases were enrolled between May 2 and June 11, 2021.

\section{Inclusion criteria}

Consecutive COVID-19-positive patients of all ages and gender notified to the Federal Capital Territory COVID-19 Control Center based in Gwagwalada were eligible for inclusion in the trial, provided informed consent was not withheld.

\section{Exclusion criteria}

Lack of a positive COVID-19, refusal to give informed consent, pregnancy, history of heart disease and known or reported allergy to any of the trial medications.

\section{Study design}

This was a single-blind, randomized, parallel group study of 2 groups of COVID-19-positive Nigerian patients with 30/31 subjects in each treatment arm. These are designated arms ' $A$ ' and ' $B$ '

A. Thirty patients received ivermectin $200 \mathrm{mcg} / \mathrm{kg}$ daily for five days.

B. 31 patients received HIA triple therapy

a. Hydroxychloroquine $200 \mathrm{mg}$ per day for three days

b. Ivermectin $200 \mathrm{mcg} / \mathrm{kg}$ daily for five days,

c. Azithromycin $500 \mathrm{mg}$ per day for three days

All three are together referred to as HIA triple therapy.

The average weight in the trial was $69.3 \mathrm{~kg}$, ranging from $51-86 \mathrm{~kg}$. Based on the weight, the patients required an average of 5 tablets of $3 \mathrm{mg}$ of ivermectin ( $15 \mathrm{mg}$ ) daily. (Range $12-21 \mathrm{mg}$ daily)

Patients across the board were also availed Standard of Care for Covid-19 patients in Nigeria including Zinc Sulfate, and vitamin C. The use of Ventilators and Oxygen was applied as needed. Three patients required oxygen therapy, one in the IVM group and two in the IVM+ group. They had baseline $\mathrm{SPO}_{2} \%$ (percentage saturation of oxygen in the blood) values of 94,78 and 89 , respectively.

Patients were to have ECG performed in case they developed palpitations. None of the patients required this.

A GeneXpert machine was used to measure quantitative reverse transcriptase polymerase chain reaction (qRT-PCR). Two different RNA particles were measured: the N-gene (nucleocapsid) and the E-gene (envelope). A semiquantitative measure of cycle threshold (Ct) values was assessed. (Time to detection is quantified by the machine. The longer it takes, the lower the viral load) All two marker genes must be 
negative before a patient is deemed negative for SARS-CoV-2. A Ct of 38 or more is regarded as negative for the E-gene, while a Ct of 40 or more is regarded as negative for the $\mathrm{N}$-gene.

\section{Sample size determination:}

The study was designed to detect a difference of $15 \%$ in the negativity rate by day 5 after dosing between the two arms ${ }^{4}$ using the Wang and Chow formula, ${ }^{20}$ giving a total of 58 patients who were rounded up to 60. However, 65 patients were recruited in the end, of whom 4 were dropped as a result of allergy to HCQ.

\section{Randomization}

A standard clinical pharmacological randomization tool was applied. Sequential patients were assigned by chance to one of 2 treatments, A, B. Patients were asked to select from a pot of rolled papers labelled $A$ or $B$. The numbers of $A=B$. This sequence was followed until the sample of $30 / 31$ was attained in each of the 2 groups.

\section{Blinding}

This was designed as a single-blind trial. The study was unmasked at the end of the trial after the analysis. However, arrangement was in place to unmask the trial in the event of a very serious adverse event.

\section{Parameters measured}

1. Viral load was assessed at enrolment (baseline) day 0, day 5, day 14 and day 21 after dosing. The proportions with negative PCR outcomes at days 5, 14 and 21 were assessed for the two groups.

2. $\mathrm{SPO}_{2} \%$ was assessed using a pulse oximeter on a daily basis at the same time of the day.

3. Symptom check list was assessed at baseline. These included the following:

Respiratory symptoms: Cough.

GIT symptoms: Nausea, vomiting, diarrhea, abdominal pain.

CVS: Tiredness, lassitude, dyspnea

CNS: Headache, Anosmia, Ageusia.

MSS: Myalgia

The following serious adverse events were monitored: dizziness, diarrhea, vomiting, nausea, appetite loss, stomach pain, tiredness, others (to be specified)

4. Inflammatory markers were measured at baseline and day 7. These were erythrocyte sedimentation rate (ESR), C-reactive protein (CRP), and D-dimer. 
5. Hematological variables were measured at baseline and day 7 , including hemoglobin, white blood cells, neutrophils, lymphocytes and platelet count. The neutrophil/lymphocyte ratio (NLR) was assessed as a measure of systemic inflammation.

\section{Statistical analyses}

Data were gathered into Android tablets on the JotForm platform and uploaded in real time to the internet cloud, making it accessible by all researchers on the team. The data were ultimately translated into Excel and cleaned. Data were subsequently updated into the STATA analysis package Stata/IC 16.1 for Mac (Intel 64-bit) and prepared for analysis.

Descriptive and inferential statistics (both parametric and nonparametric) were performed. Analysis of variance/Student's t-test and the chi-squared test were performed to assess the effects of treatment on

1. Change in Viral load over time

2. Change in Oxygen saturation over time

3. Proportion negative at fixed end points.

4. Change in the levels of inflammatory markers and hematological variables.

5. Change in clinical status over time using Likert scale: 1 Much worse/Very Bad; 2 Worse/Bad; 3 No change/average; 4 Improved/Good; 5 much improved/Very good.

6. Disposition of patients was assessed on a daily basis with regards to whether 1. treatment is maintained, 2. patient is well enough to be discharged from active care, 3. patient is referred for further treatment in intensive care, or 4 . the patient is deceased.

Repeated measures analysis of variance (RAMOVA) was carried out to simultaneously measure treatment $(A \vee B)$ differences as the treatment effect and changes over time as the TIME effect. Time $\times$ treatment interaction (whether treatment effects vary with time) was measured simultaneously on all test subjects at once for parameters indicated.

Statistical rejection of the null hypothesis was $p<0.05$, and the $95 \%$ confidence intervals were quoted.

A serious adverse event form was designed and completed for every case enrolled in the trial. A detailed clinical description of such adverse events was captured and evaluated. Immediate steps were taken to ameliorate such incidents.

\section{Results}

The baseline values for both arms of the study were compared to assess the adequacy of randomization. (Table 1). The findings suggest that there were no significant differences in the two groups (ivermectinonly IVM and the HIA triple therapy (IVM+) group) with regard to all the variables. Age and sex were similar, as were dose of ivermectin based on weight, need for supplemental oxygen, and need for ventilator. None of the patients had been vaccinated. Hematological indices such as hemoglobin, white blood count, lymphocyte and neutrophil count, neutrophil/lymphocyte ratio, and platelet count were comparable for both groups. There was also no difference with regard to viral load at baseline for either 
the $\mathrm{N}$-gene or E-gene. Inflammatory markers such as ESR, C-reactive protein, and D-dimer values were also similar in both groups. $\mathrm{SPO}_{2}$ was slightly higher for the ivermectin only (IVM) group ( $93.8 \%$ versus $92.0 \%)$, but the difference was not statistically significant $(P=0.09)$. Clinical symptoms at baseline, such as diarrhea (23.7\%), anosmia (20\%), ageusia (18\%), dyspnea (25\%), headache (50\%) and cough (72.1\%), were similar in both groups. Therefore, cough was the most common symptom with which patients presented but was slightly less common in the IVM group.

\section{Description of the study population (Table 1)}

Considering the two groups together, the average age of participants was 40.4 years, with more males (63\%) than females. Figure 1 depicts the age distribution of the study participants. This indicates that the modal age group is between $25-30$ years.

Based on the weight, the patients required an average of 5 tablets of $3 \mathrm{mg}$ each $(15 \mathrm{mg})$ daily. The hematological indices were within normal limits at baseline. These included hemoglobin $\mathrm{Hb}$, white blood cell WBC count, lymphocyte count, neutrophil count, neutrophil to lymphocyte ratio NLR, and platelet count. Viral loads at baseline were moderately high, with mean CT counts of 26.5 and 21 for the $\mathrm{N}$ and $\mathrm{E}$ genes, respectively. All these indices were similar in both groups.

With regard to the inflammatory markers, erythrocyte sedimentation rate ESR was within the normal range, but the C-reactive protein CRP was higher than normal at $14.6 \mathrm{mg} / \mathrm{l}$ compared with a normal range of less than $10 \mathrm{mg} / \mathrm{l}$.

D-dimer is the degradation product of factor XIII crosslinked fibrin. It reflects ongoing activation of the hemostatic system. The reference concentration of D-dimer was $<250 \mathrm{ng} / \mathrm{mL}$.

A mean study D-dimer level of $222.2 \mathrm{ng} / \mathrm{ml}$ was thus within normal limits.

Mean entry $\mathrm{SPO}_{2} \%$ was low at $92.9 \%$. Three of the patients had entry values of less than 80 .

In the federal capital territory where this study took place, there were six area councils (local governments). The most urbanized local governments are the Abuja Municipal Area Council (AMAC) and Gwagwalada Area Council, where the teaching hospital and the main COVID isolation center are located. The majority of the patients come from these two urbanized area councils (local governments). (Figure 2).

\section{Differential change in parameters with time over the two arms.}

Table 3 quantifies changes over time, particularly between baseline and day 7. (Except for viral gene CT, which compares baseline and day 2).

A repeated measures analysis of variance (RAMOVA) was carried out on the cycle threshold times for the $\mathrm{N}$ - and E-genes, taking into account baseline (day 0), day 2, day 5 and day 14 . There was a steady 
increase in CT values in both arms of the study. This increase was already significant by day 2 .

$(\mathrm{P}<0.0001)$. Figures 3 and 4 indicate changes in the $\mathrm{N}$-gene and $\mathrm{E}$-gene cycle thresholds, respectively, over time using adjusted predictions of treatment-by-day interactions with $95 \%$ confidence interval error bars. In both situations, there was no treatment difference between the IVM and IVM+ groups. However, there is a significant time effect $\mathrm{P}<0.0001$.

Table 2 indicates the progression of the PCR test change from 'positive' to 'negative' as the days went by. This assumes a cutoff of $\mathrm{N}-\mathrm{Ct}>38$ and $\mathrm{E}-\mathrm{Ct}>40$. negative, one in each arm. (Other authors use a cutoff point of $>35 \mathrm{Ct}$ as negative) RAMOVA of the $\mathrm{N}-\mathrm{Ct}$ and $\mathrm{E}-\mathrm{Ct}$ genes time-treatment interactions suggested that there was no treatment difference between the two arms, but there was a time effect in both arms, $P<0.0001$. There was also minimal time $x$ treatment interaction. See figures 3 and 4

Changes in $\mathrm{SPO}_{2} \%$ : RAMOVA analysis suggested that there was a significant time effect in both arms with a steady increase in $\mathrm{SPO}_{2} \%, P<0.0001$. There was a weak treatment $x$ time interaction $(P=0.10)$ from the likelihood ratio test. However, there was no significant treatment difference between the two arms $(P=0.797)$. See figure 5 .

Changes in laboratory parameters (Table 3).

Inflammatory markers: For the two arms of the study, there was a statistically significant drop in the levels of all inflammatory markers by day 7 relative to baseline. (ESR P $<0.0025$, D-dimer $P<0.0001$ and CRP, $P<0.0001$ ). (Figures 6,7,8). The drop was steeper in the IVM arm (except for CRP, where the drop was parallel), but the difference between the two groups was not statistically significant at baseline or by day 7.

Hematological variables were assessed. There was an insignificant drop in hemoglobin levels by day 7 in both arms $(P=0.138)$. However, there was a significant drop in the WBC count overall $(P<0.0002)$, with a similar degree of drop in both arms.

Overall, there was no statistically significant decrease in the lymphocyte count. However, there was a slight increase in the IVM arm of $0.27 \times 10^{9}$ cells/I as opposed to a decrease in the IVM+ arm $\left(2.2 \times 10^{9}\right)$. This difference in direction did not achieve statistical significance $(P=0.233)$. Difference $-3.16,95 \% \mathrm{Cl}$ $-8.42-2.49$

There was, however, a significant decrease in the neutrophil count across both arms compared to baseline $(P=0.0006)$, with a consequent decrease in the neutrophil to lymphocyte ratios, more so in the IVM arm. 0.23 versus 0.08 .

There was also a significant drop in the platelet counts across arms $(P<0.0001)$ more so in the IVM arm (47\% drop) than in the IVM+ arm (18.7\% drop). However, the difference in percentage drop did not achieve statistical significance. $(p=0.155)$. See Figure 9. (Actual difference was $25.895 \% \mathrm{Cl}-10.0-61.8$ ) 
Change in Clinical status with time. Figure 10. The clinical status was reported by the patients on a Likert scale in response to the question 'How do you feel today?' ranging from 1 (much worse) to 5 (much improved). Figure 10 indicates that in both arms, there was steady progress in mean wellness scores. Assuming no time treatment/interaction, there was no difference between the two groups $(P=0.760)$. However, there was a significant improvement with time in both arms. $P=0.102$ by day 2 and $P=0.000$ by day 5. By day 11, the average Likert score was over 4.5 in both arms and marginally higher in the IVM+ $\operatorname{arm}(P=0.0731)$.

The likelihood of being discharged by day 7 in either arm of the study: Patients were discharged after a negative PCR test, their perception of wellness, and the absence of concerning signs and symptoms such as fever, cough, myalgia and malaise. Sixty-three percent of patients in the IVM arm were discharged, compared to $44 \%$ in the IVM+ arm by day 7. OR $2.13(95 \% \mathrm{Cl} 0.63-7.27) \mathrm{p}=0.172$. Thus, there is a weak suggestion that patients are more likely to be discharged by day 7 in the IVM arm, but this did not achieve significance. (Table 4)

Complaints/adverse events were recorded on a daily basis and are depicted in Figure 11. It is difficult to know which complaints are due to the disease and which are due to the drug, but all are assessed together. A total of 11 patients had complaints of one form or the other on the first day of treatment, 8 in the IVM group and 3 in the IVM+ group. Complaints in the IVM group included tiredness (4) and stomach pain, nausea, vomiting and dizziness. Only 3 people had complaints of stomach pain in the IVM+ group. By day 2, 4 people still complained of tiredness, and two of stomach pain in the IVM arm, while 3 people complained of tiredness in the IVM+ arm. There was an overall decrease in the number of complaints by day 5 , by which time only 3 people complained.

Overall, there were 23 complaint events in the IVM group compared to 14 in the IVM+ group. However, four subjects in the IVM+ group had been dropped from the study because of reaction to HCQ and did not form part of this analysis. Their reaction, mainly consisting of itchiness, had not responded to loratadine. Two other subjects developed severe itching around the armpits attributable to HCQ but were successfully treated with Loratadine and so continued in the study and formed part of this analysis.

\section{Discussion}

The clinical, virological, inflammatory, and respiratory $\left(\mathrm{SPO}_{2} \%\right)$ comparative assessments, which are hard end points of our randomized controlled study, did not show a significant difference between IVM monotherapy and HIA triple therapy in RT-PCR-positive COVID-19 patients. This finding indicates that a combination of AZT + HCQ did not confer any additive benefit to IVM in virucidal action against SARSCov-2. The results, however, confirm and extend our earlier results on the anti-SARS-CoV-2 efficacy of ivermectin alone ${ }^{4}$.

In this study, we demonstrate further that ivermectin alone or with HIA rapidly increased the cycle time (Ct) of the N-gene (nucleocapsid) and the E-gene (envelope) of SARS-CoV-2 and achieved significant 
COVID negativity on day 7 on RAMOVA (see Figures 3 and 4).

The possible explanation of the lack of additional or superior efficacy of HIA over IVM is not clear. First, it can be postulated that IVM, with its multiple mechanisms of anti-SARS-CoV-2 actions ${ }^{4,5}$, which incidentally includes the modes of action of both AZT and HCQ ${ }^{6,7,8,9,14,15}$, early onset pharmacodynamics and near maximal efficacy, leaves no opportunity for enhanced efficacy for azithromycin and HCQ, which have a higher IC50 for SARS-CoV-2 inhibition ${ }^{12,13}$. It is likely that drugs with divergent mechanisms of anti-SARS-CoV-2, such as molnupiravir5, may exhibit synergism in virucidal activity when combined with IVM.

Although some studies indicated the benefit of AZT + HCQ in COVID 196,21, this is not a universal finding 22 . HCQ was discontinued in the RECOVERY study because of lack of efficacy and cardiac adverse effects $^{19}$

Additionally, it has been reported that HCQ/CQ does not inhibit SARS-CoV-2 in human lung cells/Calu-2 cells ${ }^{23}$.

HCQ is also less efficient in blocking viral cell entry in Vero-6 cells and in inhibiting viral replication in the lungs 24,25 .

It is thus plausible that AZT + HCQ was effectively a placebo in the combination and did not exert any independent virucidal activity.

CQ/HCQ exerted no cardiac adverse effects that had been reported in other populations, as no patient had any cardiac dysrhythmic symptoms. This safe cardiac trend is compatible with experience with chloroquine treatment of malaria in this hyperendemic zone for more than half a century. Interethnic differences in QT elongation response to chloroquine have also been noted by Shah et al, ${ }^{26}$ who suggested that Africans may not be as prone as Caucasians to CQ-induced cardiotoxicity.

IVM and HIA were associated with improved $\mathrm{SPO}_{2} \%$ over 7 days by RAMOVA (see Figure 5). Although no treatment difference was discernible, the time effect of $p<0.0001$ was likely due to treatment with ivermectin in both arms, as it was shown to increase $\mathrm{SPO}_{2} \%$ in our earlier study ${ }^{4}$. This is highly suggestive of the prevention or reversal of any respiratory vascular damage, which is a hallmark of COVID-19.

IVM and HIA were both associated with significantly reduced pro-inflammatory markers CRP, ESR and Ddimer (Figures 6-8), indicative of antithrombotic and cytokine reduction effects of ivermectin via STAT-3 inhibition, as we have previously suggested ${ }^{4}$.

Possible side effects of ivermectin: As noted above, there was an overall decrease in the number of complaints by day 5 . This suggests that the dose of ivermectin used in this study is safe and efficacious. 
In conclusion, there was no significant treatment difference between IVM monotherapy and HIA triple therapy, thus suggesting that AZT + HCQ may be a redundant adjuvant in COVID-19 therapy in Nigerians and elsewhere. There was a highly significant time effect $(P<0.0001$ RAMOVA), indicating that the improvements in SARS-CoV-2 N and E-gene $\mathrm{Ct}$, as well as the $\mathrm{SPO}_{2} \%$, are likely due in large part to ivermectin virucidal and anti-inflammatory actions.

\section{Declarations}

Trial ID: PACTR202108891693522

Acknowledgments: Tobi Babalola for work on the data collection platform.

Funding: Central Bank of Nigeria. Healthcare Sector Research and Development Intervention Scheme (HSRDIS)

\section{References}

1. WHO Statement on the second meeting of the International Health Regulations (2005) Emergency Committee regarding the outbreak of novel coronavirus (2019-nCoV). 2020. https://www.who.int/news-room/detail/30-01-2020-statement-on-the-second-meeting-of-theinternational-health-regulations-(2005)-emergency-committee-regarding-the-outbreak-of-novelcoronavirus-(2019-ncov). Accessed 2nd 2020.

2. WHO Coronavirus (COVID-19) Dashboard. Covid19.who.int. Accessed 11th September 2020.

3. Centers for Disease Control and Prevention. Delta variant: What we know about the science. August 26.2021. https://www.cdc.gov/coronavirus/2019-ncov/variants/delta-variant.html.

4. Babalola OE, Bode CO, Ajayi AA, Alakaloko FM, Akase IE, Otrofanowei E, Salu OB, Adeyemo WL, Ademuyiwa AO, Omilabu S. Ivermectin shows clinical benefits in mild to moderate COVID19: a randomized controlled double-blind, dose-response study in Lagos, QJM: An International Journal of Medicine, 2021; hcab035, https://doi.org/10.1093/qjmed/hcab035

5. Ajayi AA. Drugs Shown to Inhibit SARS-CoV-2 in COVID-19 Disease: Comparative Basic and Clinical Pharmacology of Molnupiravir and Ivermectin. Austin J Pharmacol Ther. 2021; 9(5).1149.

6. Gautret, P. et al. Hydroxychloroquine and azithromycin as a treatment of COVID-19: results of an open-label non-randomized clinical trial. Int. J.

7. Raoult D et al. COVID-19 Therapeutic and Prevention. doi: 10.1016/j.jjantimicag.2020.105937. Epub 2020 Mar 7

8. Boulware DR, Pullen MF, Bangdiwala AS, et al. A randomized trial of hydroxychloroquine as postexposure prophylaxis for covid-19. NEJM. June 2020. .

9. Hooks M, Bart B, Vardeny O, Westanmo A and Adabaq S. Effects of hydroxychloroquine treatment on QT interval. Published:June 28,2020DOI:https://doi.org/10.1016/j.hrthm.2020.06.029 21. 
10. Caly L, Druce JD, Catton MG, Jans DA, Wagstaff KM. The FDA-approved drug Ivermectin inhibits the replication of SARS-CoV-2 in vitro. Antiviral Research. Volume 178, June 2020, 104787

11. Portmann-Baracco A, Bryce-Alberti M, and Accinelli RA. Antiviral and anti-inflammatory properties of Ivermectin and its potential use in Covid 19. Arch Bronconeumol. 2020 Dec; 56(12): 831.doi: 10.1016/j.arbr.2020.06.006

12. Weston S, Coleman CM, Sisk JM, Haupt R, Logue J, Matthews K, Frieman MB. Broad anti-coronaviral activity of FDA approved drugs against SARS-CoV-2 in vitro and SARS-CoV in vivo. bioRxiv. 2020 doi: 10.1101/2020.03.25.008482.

13. Hoffmann M, Mösbauer K, Hofmann-Winkler, H. et al. Chloroquine does not inhibit infection of human lung cells with SARS-CoV-2. Nature 585, 588-590 (2020). https://doi.org/10.1038/s41586020-2575-3

14. Li X, Wang, Y, Agostinis P. et al. Is hydroxychloroquine beneficial for COVID-19 patients? Cell Death Dis 11, 512 (2020). https://doi.org/10.1038/s41419-020-2721-8

15. Poschet JF, Perkett EA, Timmins GS. Azithromycin and ciprofloxacin have a chloroquine-like effect on respiratory epithelial cells. BioRxiv, p. 01-21, Mar. 2020

16. Touret F, Gilles M, Barral K. et al. In vitro screening of a FDA approved chemical library reveals potential inhibitors of SARS-CoV-2 replication. Sci Rep 10, 13093 (2020). https://doi.org/10.1038/s41598-020-70143-6

17. Damle B, Vourvahis M, Wang E, Leaney J, Corrigan B. Clinical Pharmacology Perspectives on the Antiviral Activity of Azithromycin and Use in COVID-19. Clin Pharmacol Ther. 2020 Aug;108(2):201211. doi: 10.1002/cpt.1857. Epub 2020 May 12. PMID: 32302411; PMCID: PMC7262099.

18. Gautret P. et al. Hydroxychloroquine and azithromycin as a treatment of COVID-19: results of an open-label non-randomized clinical trial. Int. J.)Antimicrob.Agents 105949. https://doi.org/10.1016/j.ijantimicag (2020)

19. RECOVERY Collaborative Group, Horby P, Mafham M, Linsell L, et al. Effect of Hydroxychloroquine in Hospitalized Patients with Covid-19. N Engl J Med. 2020 Nov 19;383(21):2030-2040. doi: 10.1056/NEJMoa2022926. Epub 2020 Oct 8. PMID: 33031652; PMCID: PMC7556338.

20. Wang $\mathrm{H}$ and Chow SC. 2007. Sample Size Calculation for Comparing Proportions. Wiley Encyclopedia of Clinical Trials. https://onlinelibrary.wiley.com/doi/abs/10.1002/9780471462422.eoct005

21. Andreani J, Le Bideau M, Duflot I, Jardot P, Rolland C, Boxberger M, Wurtz N, Rolain JM, Colson P, La Scola B, Raoult D. In vitro testing of combined hydroxychloroquine and azithromycin on SARS-CoV-2 shows synergistic effect. Microb Pathog. 2020 Aug;145:104228. doi: 10.1016/j.micpath.2020.104228. Epub 2020 Apr 25. PMID: 32344177; PMCID: PMC7182748.

22. Maisonnasse P, Guedj J, Contreras V. et al. Hydroxychloroquine use against SARS-CoV-2 infection in non-human primates. Nature 585, 584-587 (2020). https://doi.org/10.1038/s41586-020-2558-4

23. Hoffmann M, Mösbauer K, Hofmann-Winkler H, Kaul A, Kleine-Weber H, Krüger N, Gassen NC, Müller MA, Drosten C, Pöhlmann S. Chloroquine does not inhibit infection of human lung cells with SARS- 
CoV-2. Nature. 2020 Sep;585(7826):588-590. doi: 10.1038/s41586-020-2575-3. Epub 2020 Jul

24. Weston S, Coleman CM, Haupt R, Logue J, Matthews K, Li Y, Reyes HM, Weiss SR, Frieman MB. Broad Anti-coronavirus Activity of Food and Drug Administration-Approved Drugs against SARS-CoV-2 In Vitro and SARS-CoV In Vivo. J Virol. 2020 Oct 14;94(21):e01218-20. doi: 10.1128/JVI.01218-20. PMID: 32817221; PMCID: PMC7565640.

25. Kashour Z, Riaz M, Garbati MA, AIDosary O, Tlayjeh H, Gerberi D, Murad MH, Sohail MR, Kashour T, Tleyjeh IM. Efficacy of chloroquine or hydroxychloroquine in COVID-19 patients: a systematic review and meta-analysis. J Antimicrob Chemother. 2021 Jan 1;76(1):30-42. doi: 10.1093/jac/dkaa403. PMID: 33031488; PMCID: PMC7665543.

26. Shah RR. Drug-induced QT interval prolongation: does ethnicity of the thorough QT study population matter? Br J Clin Pharmacol. 2013 Feb;75(2):347-58. doi: 10.1111/j.1365-2125.2012.04415.x. PMID: 22882246; PMCID: PMC3579250.

\section{Tables}

Table 1. Baseline variables 


\begin{tabular}{|c|c|c|c|c|}
\hline Variable & $\begin{array}{l}\text { IVM only } \\
\text { Group A }\end{array}$ & $\begin{array}{l}\text { HCQ+ IVM } \\
+ \text { AZM (HIA) } \\
\text { Group B }\end{array}$ & Overall & P value (test) \\
\hline Total Numbers & 30 & 31 & 61 & \\
\hline Mean Age (SD)years. & $41.6(2.6)$ & $39.2(2.9)$ & $40.4(1.9)$ & 0.558 (ttest) \\
\hline Sex (Male \%) & $20(66)$ & $19(61)$ & $39(63)$ & 0.662 (chi2) \\
\hline $\begin{array}{l}\text { Dose of Ivermectin } \\
\text { (number of } 3 \mathrm{mg} \text { tablets) }\end{array}$ & $5.07(0.12)$ & $5.07(0.13)$ & $5.07(0.69)$ & 0.98 (ttest) \\
\hline Oxygen use & 1 & 2 & 3 & 0.573 (chi2) \\
\hline Ventilator & 2 & 0 & 2 & $\begin{array}{l}0.144 \text { (Pearson } \\
\text { Chi) }\end{array}$ \\
\hline Vaccination & 0 & 0 & 0 & \\
\hline \multicolumn{5}{|l|}{ Hematology } \\
\hline Hemoglobin g/dl & $12.9(2.4)$ & $12.6(2.4)$ & $12.7(2.4)$ & 0.577 \\
\hline WBC X109 cells/liter & $9.76(2.84)$ & $9.33(2.13)$ & $9.53(2.49)$ & 0.501 \\
\hline Lymphocyte X109 cells/liter & $32.4(13.0)$ & $37.4(13.6)$ & $34.9(13.5)$ & 0.150 \\
\hline $\begin{array}{l}\text { Neutrophils } \\
\mathrm{X} 10^{9} \text { cells/liter }\end{array}$ & $58.6(15.3)$ & $59.8(12.5)$ & $59.2(13.9)$ & 0.723 \\
\hline $\begin{array}{l}\text { Neutrophil to Lymphocyte } \\
\text { ratio(NLR) }\end{array}$ & 2.49 & 2.05 & 2.27 & 0.443 \\
\hline $\begin{array}{l}\text { Platelet count } \\
\text { X109 cells/liter }\end{array}$ & $211.5(62.3)$ & $196.9(55.5)$ & $204.1(58.9)$ & 0.341 \\
\hline \multicolumn{5}{|l|}{ Viral Load Cycle Threshold Ct. } \\
\hline $\mathrm{N}$-gene CT & $27.4(1.03)$ & $25.7(1.14)$ & $26.5(6.02)$ & 0.27 (ttest) \\
\hline E-gene CT & $21.2(0.75)$ & $20.7(20.9)$ & 21 & 0.654 \\
\hline \multicolumn{5}{|l|}{ Inflammatory markers } \\
\hline ESR ml/h Westergren & $12.8(0.51)$ & $12.7(0.43)$ & $12.78(0.33)$ & 0.816 (ttest) \\
\hline C-reactive Protein $\mathrm{mg} / \mathrm{l}$ & $14.7(1.01)$ & $14.7(1.01)$ & $14.67(0.71)$ & 0.995 (ttest) \\
\hline $\begin{array}{l}\text { D-dimer ng/ml FEU } \\
\text { (Fibrinogen equivalent Unit) }\end{array}$ & $\begin{array}{l}223.9 \\
(18.8)\end{array}$ & $220.5(21.6)$ & $222.2(28.2)$ & 0.525 (ttest) \\
\hline $\mathrm{SPO}_{2} \%$ & $93.8(3.5)$ & $92.0(4.7)$ & $92.9(4.2)$ & 0.09 (ttest) \\
\hline \multicolumn{5}{|l|}{ Symptoms at baseline (\%) } \\
\hline Diarrhea & $6(20)$ & $8(27.6)$ & $14(23.7)$ & $0.493\left(\mathrm{chi}^{2}\right)$ \\
\hline Anosmia & $6(20)$ & $6(20)$ & $12(20)$ & $1.000\left(\mathrm{chi}^{2}\right)$ \\
\hline Ageusia & $5(16.7)$ & $6(19.3)$ & $11(18.0)$ & $\begin{array}{l}0.785 \\
\text { (Fisher's } \\
\text { exact) }\end{array}$ \\
\hline Dyspnea & $8(26.7)$ & $7(23.3)$ & 15(25) & $\begin{array}{l}0.766 \\
\text { (Fisher's } \\
\text { exact) }\end{array}$ \\
\hline Headache & $14(46.7)$ & $16(53.3)$ & $30(50)$ & $\begin{array}{l}0.606 \\
\text { Fisher's } \\
\text { exact) }\end{array}$ \\
\hline Cough & $20(66.7)$ & $24(77.4)$ & $44(72.1)$ & 0.349 \\
\hline
\end{tabular}

Table 2. PCR results (positive/negative) by day in the study by treatment arm. 


\begin{tabular}{|c|c|c|c|c|c|}
\hline Day & Arm & PCR Positive & $\begin{array}{l}\text { PCR Negative } \\
\text { (Row\%) }\end{array}$ & Total & $\begin{array}{l}\text { P value } \\
\text { (OR 95\%CI) }\end{array}$ \\
\hline \multirow[t]{3}{*}{ Baseline } & IVM & 30 & $0(0)$ & 30 & \\
\hline & IVM+ & 31 & $0(0)$ & 31 & \\
\hline & Total & 61 & $0(0)$ & 61 & \\
\hline \multirow[t]{3}{*}{ Day 2} & IVM & 30 & $0(0)$ & 30 & \multirow[t]{3}{*}{0.313} \\
\hline & IVM+ & 29 & $1(3.33)$ & 30 & \\
\hline & Total & 59 & $1(1.67)$ & 60 & \\
\hline \multirow[t]{3}{*}{ Day 5} & IVM & 21 & $9(30.0)$ & $30(100)$ & \multirow{3}{*}{$\begin{array}{l}0.584 \\
(1.35,0.403-4.571)\end{array}$} \\
\hline & IVM+ & 19 & $11(36.7)$ & $30(100)$ & \\
\hline & Total & 40 & $20(34.5)$ & $60(100)$ & \\
\hline \multirow[t]{3}{*}{ Day 14} & IVM & $1(3.5)$ & $28(96.6)$ & 29 & $\begin{array}{l}1.000 \\
\text { (1. } 0.012-81.2)\end{array}$ \\
\hline & IVM+ & $1(3.5)$ & $28(96.6)$ & 29 & \\
\hline & Total & 2 & $56(96.6)$ & 58 & \\
\hline \multirow[t]{3}{*}{ Day 21} & IVM & $29(100)$ & 0 & 29 & \\
\hline & IVM+ & $29(100)$ & 0 & 29 & \\
\hline & Total & 58 & 0 & 58 & \\
\hline
\end{tabular}

Table 3. Changes in laboratory parameters in both arms of the study over time. 


\begin{tabular}{|c|c|c|c|c|}
\hline Parameter & Baseline & $\begin{array}{l}\text { Day } \\
7\end{array}$ & $\begin{array}{l}\text { Change } \\
\text { Baseline-day7. } \\
\text { (*day2-baseline) }\end{array}$ & $\begin{array}{l}\text { P value } \\
\text { Top: Day7-baseline } \\
\text { Bottom: Difference between } \\
\text { arms at day7 }\end{array}$ \\
\hline \multicolumn{5}{|c|}{$\begin{array}{l}\text { Inflammatory } \\
\text { markers }\end{array}$} \\
\hline \multicolumn{5}{|l|}{ ESR } \\
\hline Study Total & 12.8 & 11.4 & 1.37 & 0.0025 \\
\hline IVM & 12.9 & 10.98 & 1.88 & \multirow{2}{*}{\begin{tabular}{|l}
0.257 \\
0.257 \\
\end{tabular}} \\
\hline IVM+ & 12.7 & 11.91 & 0.86 & \\
\hline \multicolumn{5}{|c|}{ C-reactive Protein } \\
\hline Study total & 14.7 & 5.6 & 9.00 & \multirow{3}{*}{\begin{tabular}{|l}
$<0.0001$ \\
0.743
\end{tabular}} \\
\hline IVM & 14.7 & 5.9 & 6.9 & \\
\hline IVM+ & 14.7 & 5.4 & 7.4 & \\
\hline \multicolumn{5}{|l|}{ D-Dimer FEU } \\
\hline Study total & 221.8 & 171.2 & 50.55 & \multirow{3}{*}{\begin{tabular}{|l|}
$<0.0001$ \\
0.221
\end{tabular}} \\
\hline IVM & 223.9 & 164.5 & 59.4 & \\
\hline IVM+ & 220.6 & 178.1 & 41.7 & \\
\hline \multicolumn{5}{|l|}{ Hematology } \\
\hline \multicolumn{5}{|l|}{ Hemoglobin } \\
\hline Study Total & 12.7 & 12.1 & 0.56 & \multirow{3}{*}{$\begin{array}{l}0.138 \\
0.615\end{array}$} \\
\hline IVM & 12.9 & 12.3 & 0.67 & \\
\hline IVM+ & 12.6 & 12.1 & 0.44 & \\
\hline \multicolumn{5}{|l|}{ WBC } \\
\hline Study Total & 9.5 & 7.9 & 1.62 & \multirow{3}{*}{\begin{tabular}{|l|}
0.0002 \\
0.75
\end{tabular}} \\
\hline IVM & 9.8 & 8.0 & 1.75 & \\
\hline IVM+ & 9.3 & 7.8 & 1.49 & \\
\hline \multicolumn{5}{|l|}{ lymphocytes } \\
\hline Study total & 34.9 & 33.5 & 1.3 & 0.322 \\
\hline IVM & 32.4 & 32.7 & -0.27 & \multirow[t]{2}{*}{0.233} \\
\hline IVM+ & 37.3 & 34.4 & 2.2 & \\
\hline \multicolumn{5}{|l|}{ Neutrophils } \\
\hline Study total & 59.2 & 51.8 & 7.31 & \multirow{3}{*}{\begin{tabular}{|l|}
0.0006 \\
0.838 \\
\end{tabular}} \\
\hline IVM & 58.6 & 51.7 & 6.9 & \\
\hline IVM+ & 59.8 & 52.1 & 7.7 & \\
\hline \multicolumn{5}{|c|}{ Neutrophil to Lymphocyte ratio (NLR) } \\
\hline Study total & 1.70 & 1.55 & 0.15 & \\
\hline IVM & 1.81 & 1.58 & 0.23 & \\
\hline IVM+ & 1.60 & 1.52 & 0.08 & \\
\hline \multicolumn{5}{|c|}{ Platelet count X109/liter } \\
\hline Study total & 204.1 & 153.8 & 49.7 & $<0.0001$ \\
\hline IVM & 211.5 & 148.8 & 62.7 & \multirow{2}{*}{0.155} \\
\hline IVM+ & 197 & 158.7 & 36.8 & \\
\hline \multicolumn{5}{|c|}{$\begin{array}{l}\text { N-gene Viral Cycle } \\
\text { Time }\end{array}$} \\
\hline Study total & 26.5 & 33.8 & $7.04 *$ & \multirow{3}{*}{$\begin{array}{l}<0.0001 \\
0.425\end{array}$} \\
\hline IVM & 27.4 & 33.7 & $6.42^{*}$ & \\
\hline IVM+ & 25.7 & 33.8 & $7.68^{*}$ & \\
\hline \multicolumn{5}{|l|}{$\begin{array}{l}\text { E-gene Viral } \\
\text { Cycle Time }\end{array}$} \\
\hline Study total & 20.9 & 28.6 & $7.62 *$ & \\
\hline IVM & 21.2 & 27.8 & $6.53 *$ & 0.133 \\
\hline IVM+ & 20.7 & 29.5 & $8.71 *$ & \\
\hline $\mathrm{SPO}_{2}$ & & & & \\
\hline Study total & 92.9 & 97.7 & 4.78 & $<0.0001$ \\
\hline
\end{tabular}




\begin{tabular}{|l|l|l|l|l|} 
IVM & 93.8 & 97.8 & 3.5 & 0.0189 \\
\hline IVM+ & 92 & 97.5 & 6 & \\
\hline
\end{tabular}

\section{Figures}

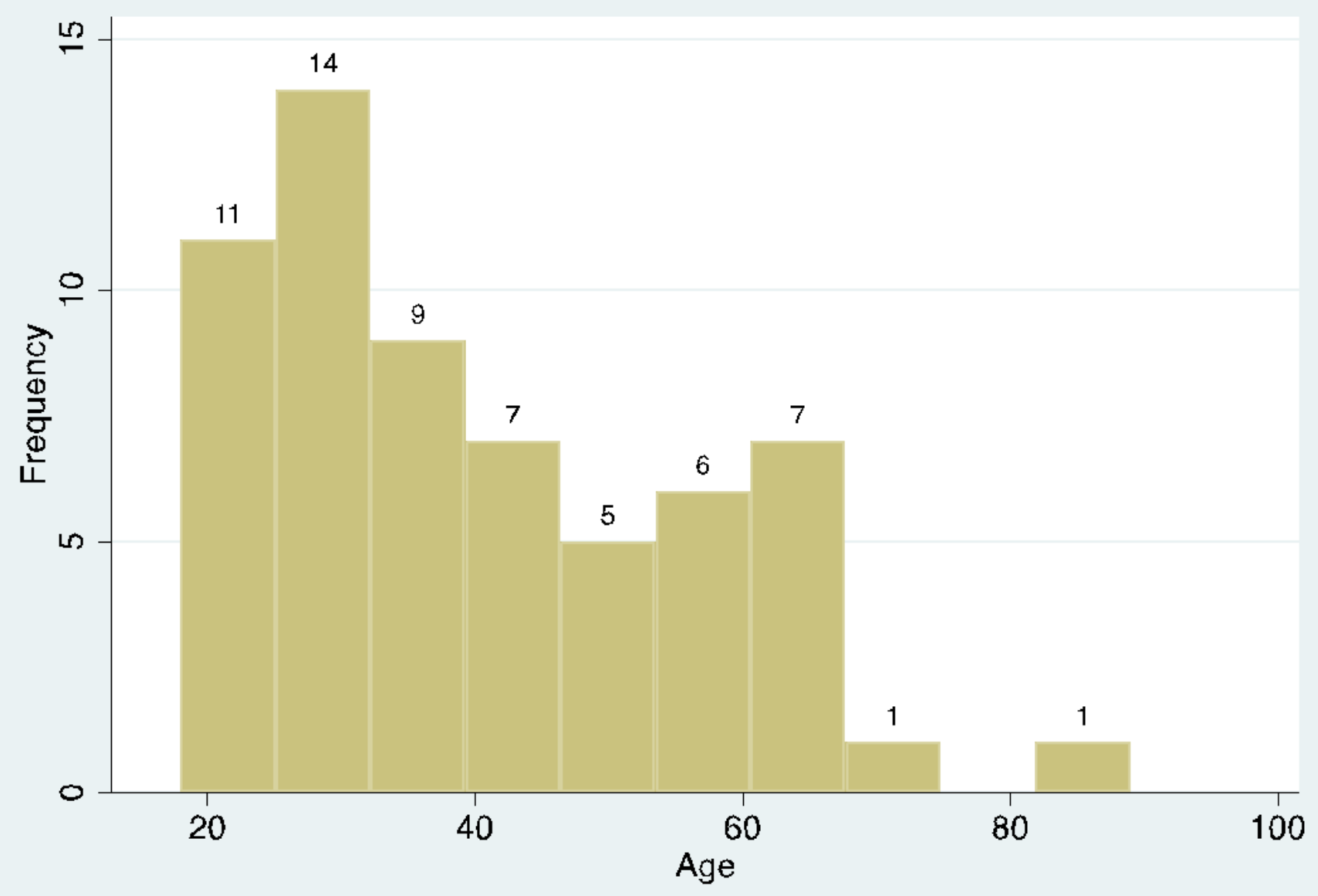

Age distribution of Study population

\section{Figure 1}

Histogram depicting age distribution of the patients 


\section{Distribution of patients by Local Government}

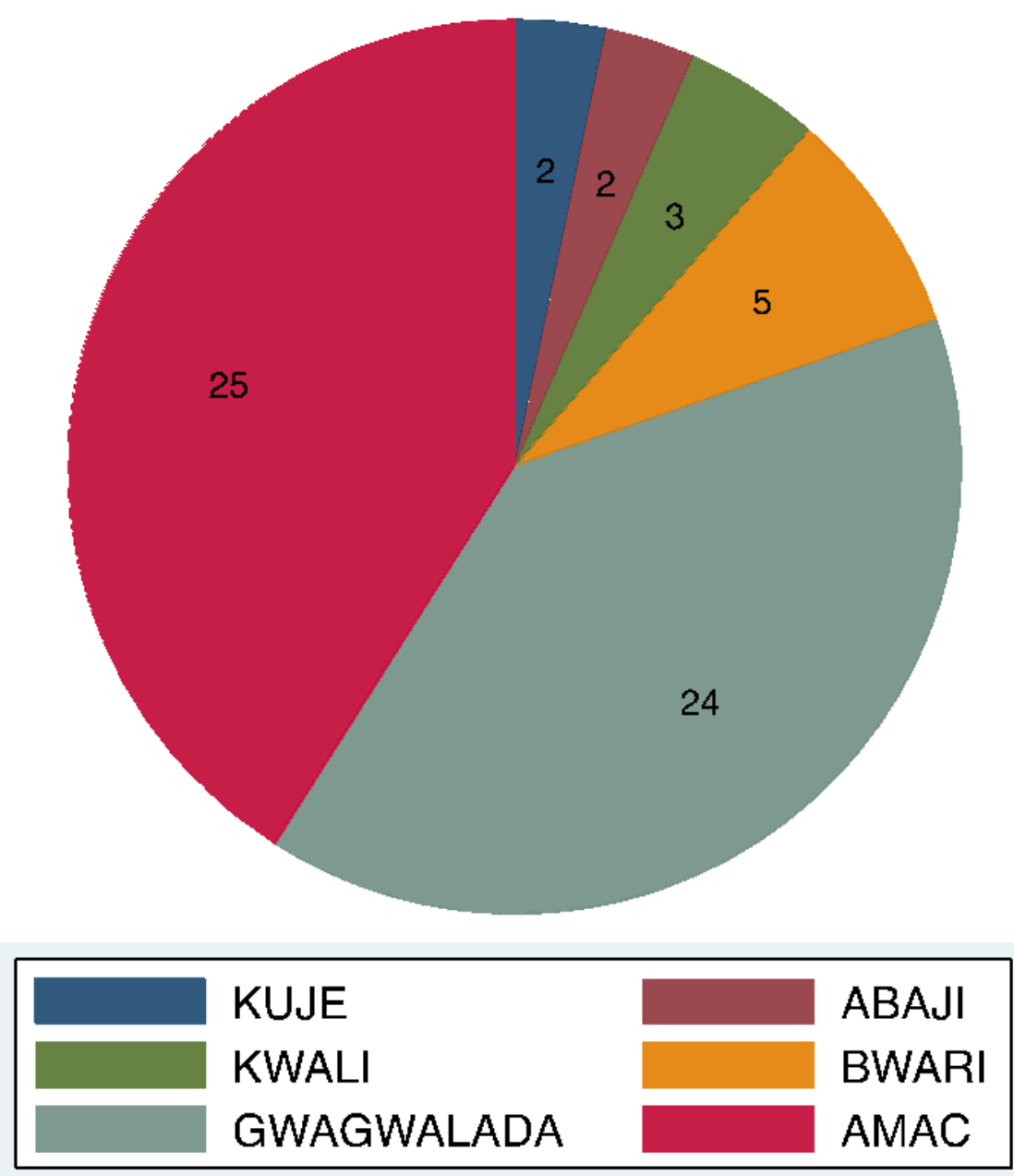

Figure 2

Distribution of patients by Area Council within the Federal Capital Territory 


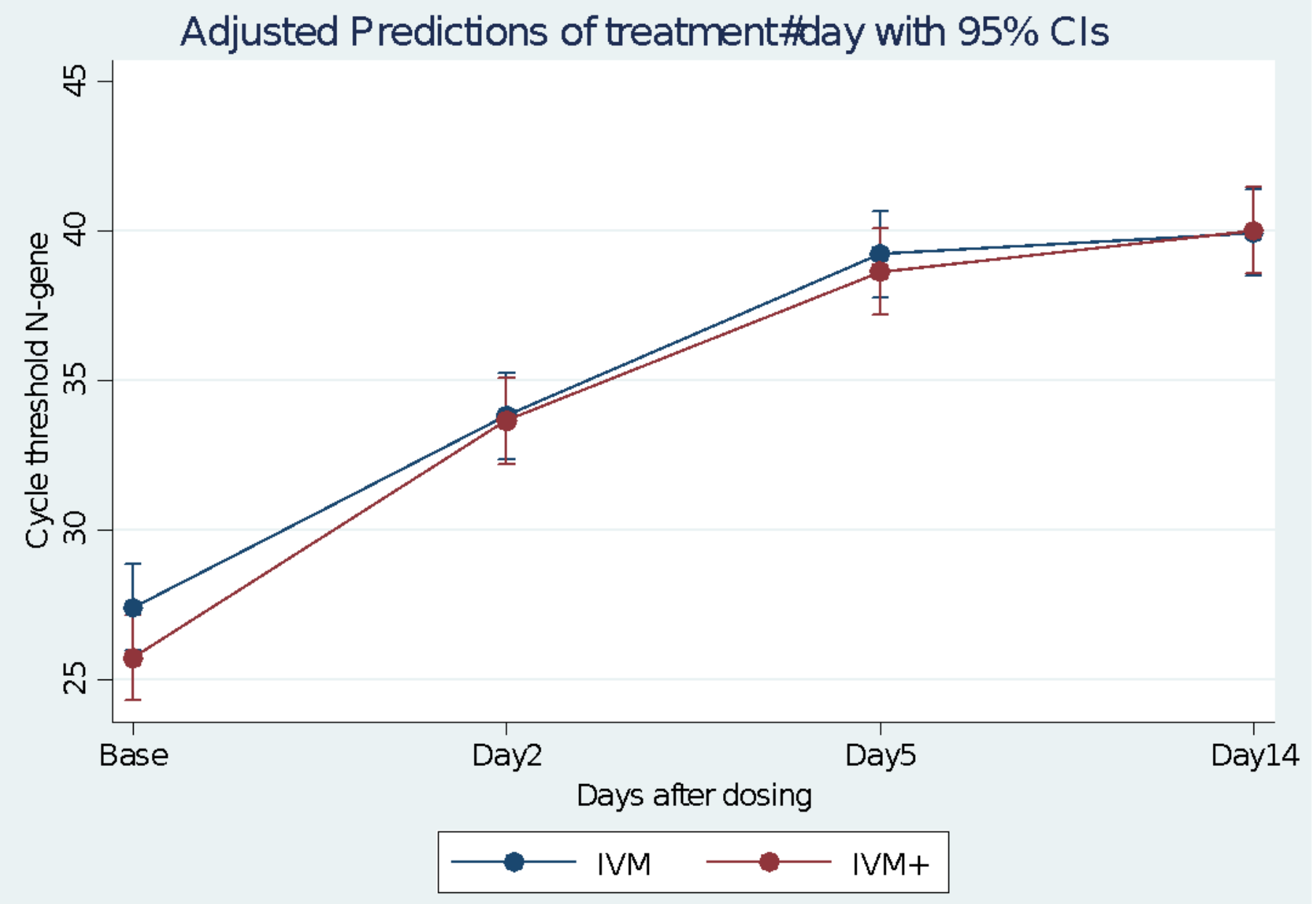

Figure 3

Change in N-gene cycle threshold over time using adjusted predictions of treatment-by-day interaction with $95 \%$ confidence interval error bars. RAMOVA $n=30$ No significant treatment effect, but a significant time effect, $p<0.0001$ ANOVA. There was no time-treatment interaction. 


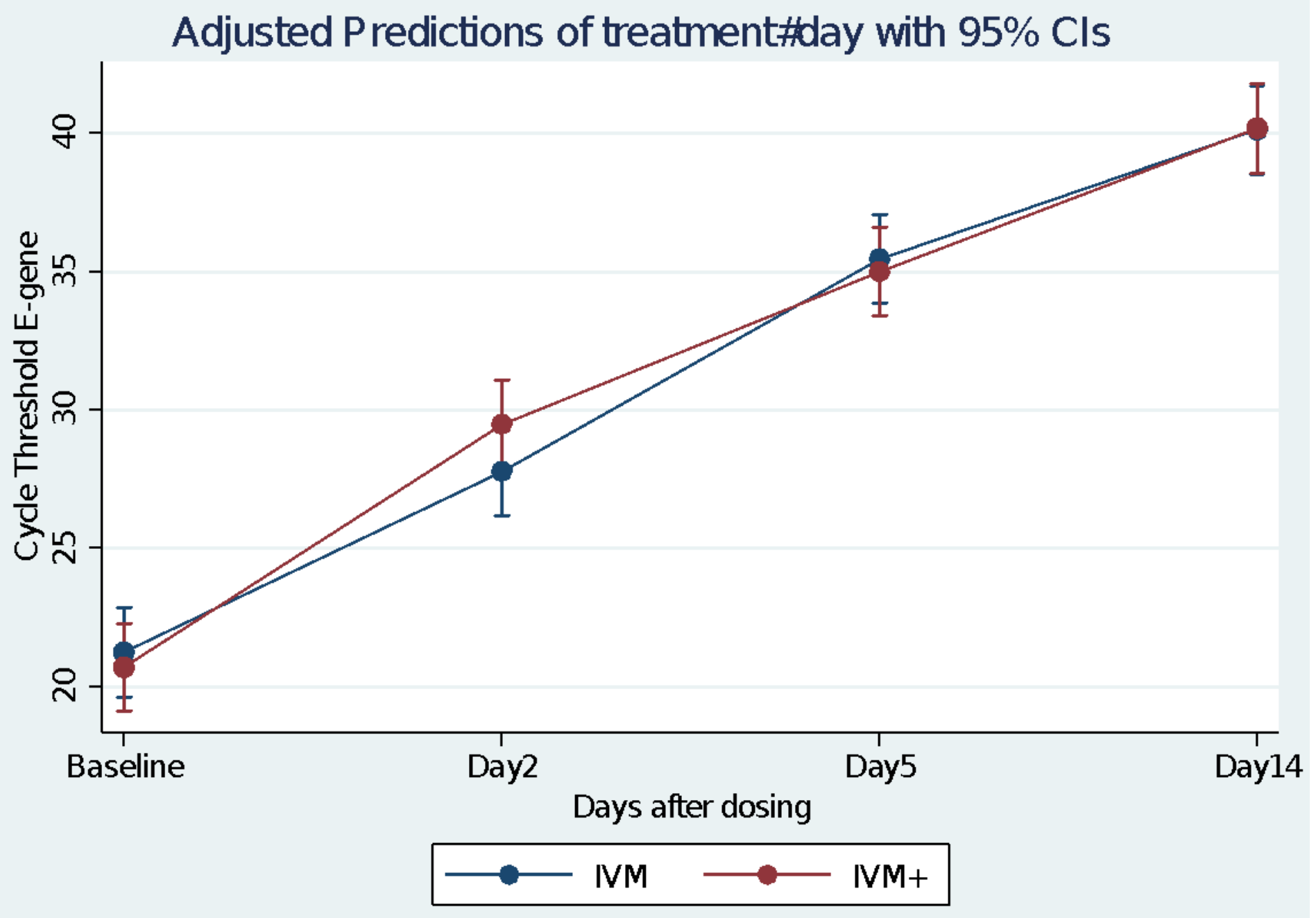

Figure 4

Change in E-gene Cycle threshold over time using Adjusted Predictions of treatment-by-Day interaction with $95 \%$ Confidence Interval error bars. RAMOVA. $n=30$. No Treatment Effect by 2-way repeated measures ANOVA. There was a significant Time effect, $p<0.0001$ ANOVA. No time $x$ treatment interactions. 


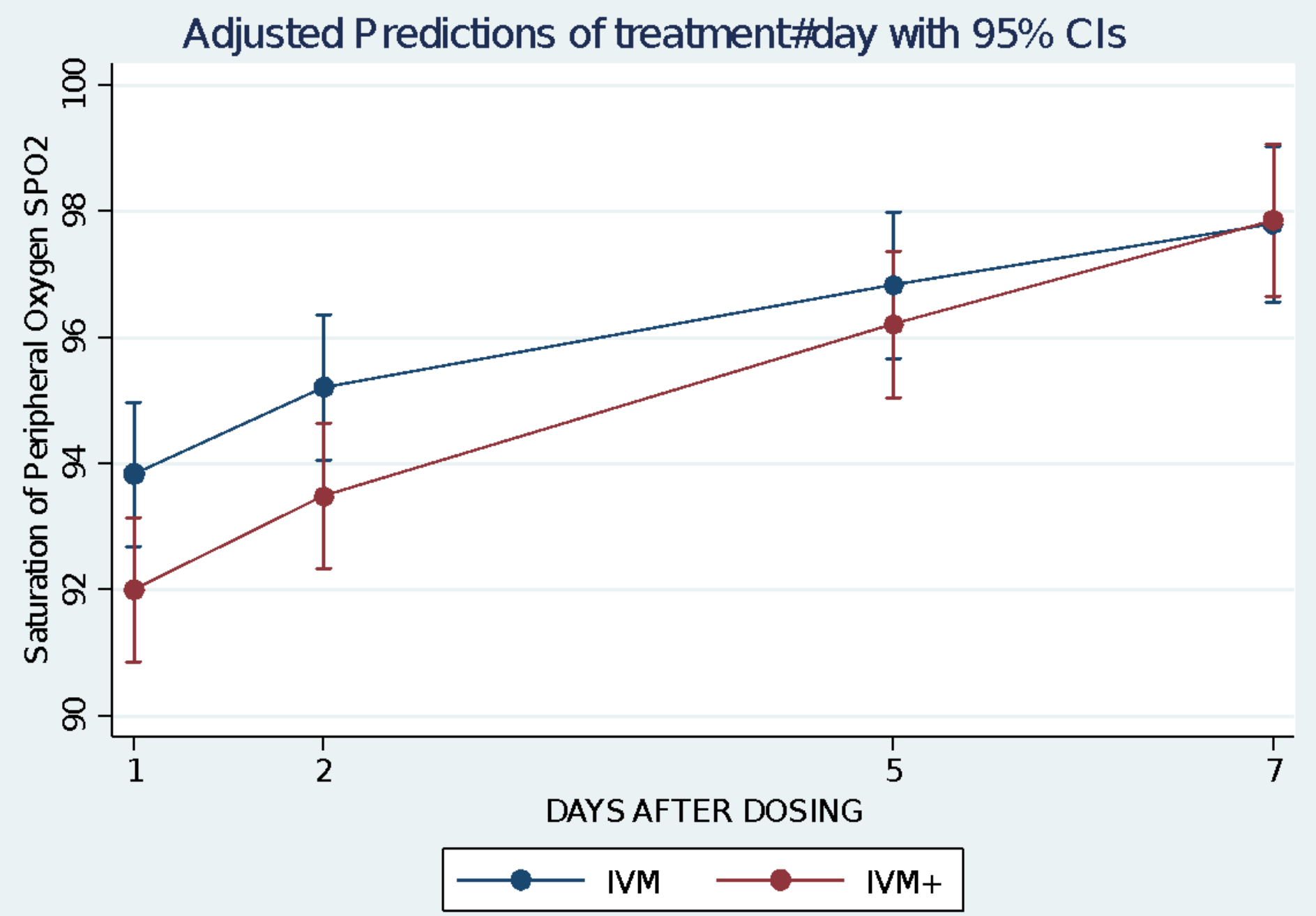

Figure 5

Change in arterial oxygen saturation SPO2 over time using adjusted predictions of treatment-by-day interaction with $95 \%$ confidence interval error bars. 


\section{Changes in D-dimer levels}

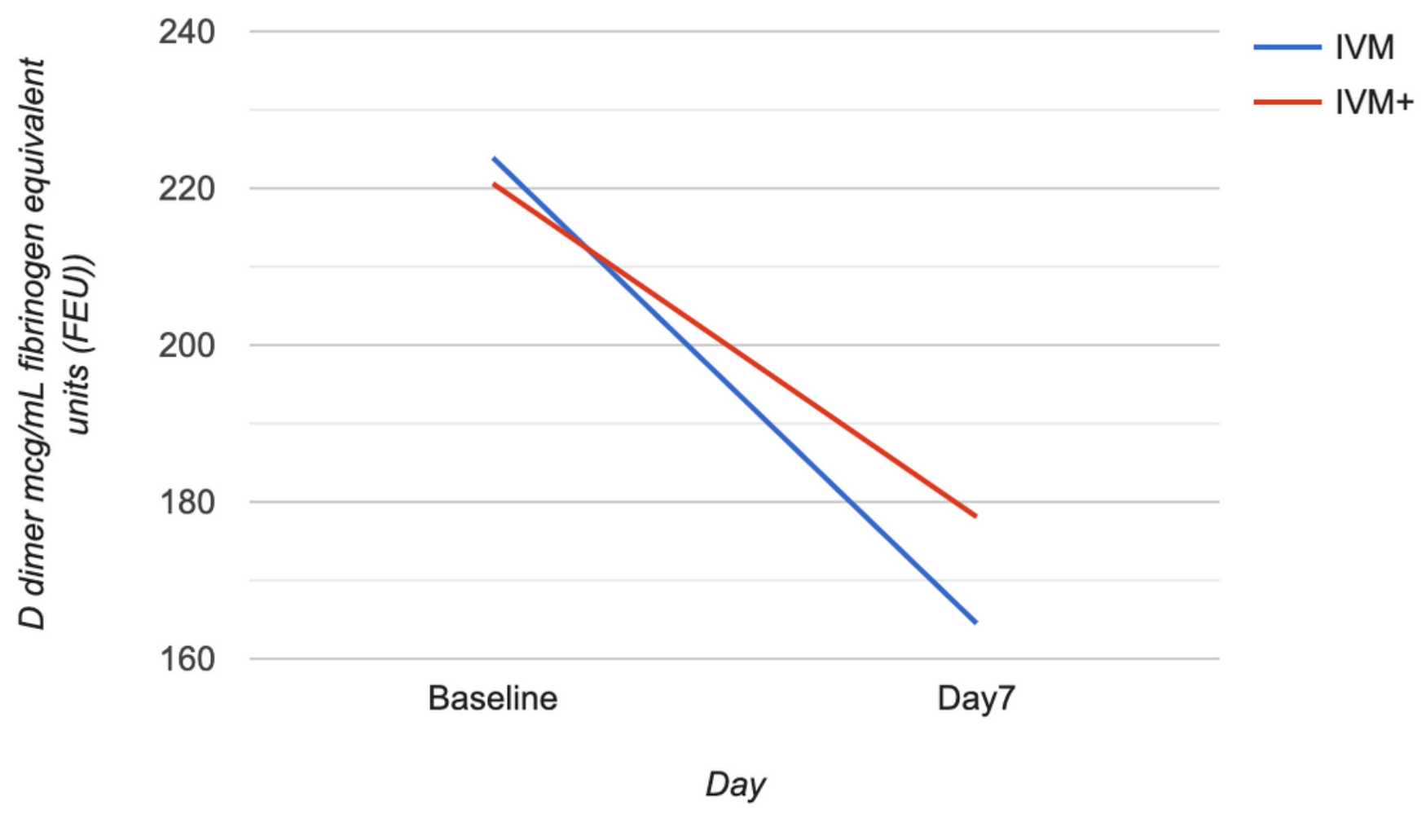

Figure 6

Change in D-dimer levels from baseline to day 7 in the IVM and IVM+ treatment arms. 


\section{Changes in C-Reactive Protein levels}

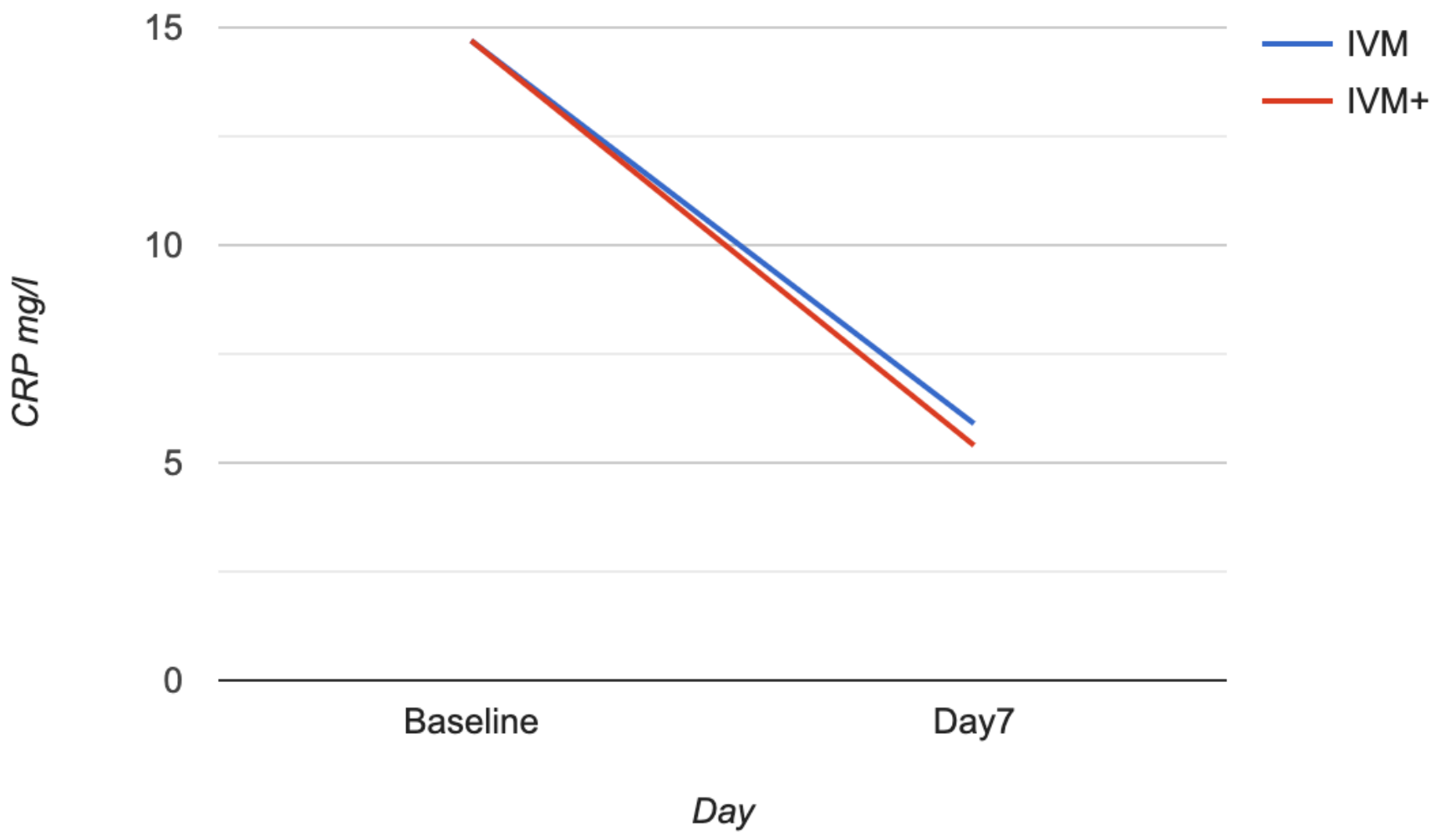

Figure 7

Change in C-reactive protein levels from baseline to day 7 in the IVM and IVM+ treatment arms. 


\section{Changes in ESR levels}

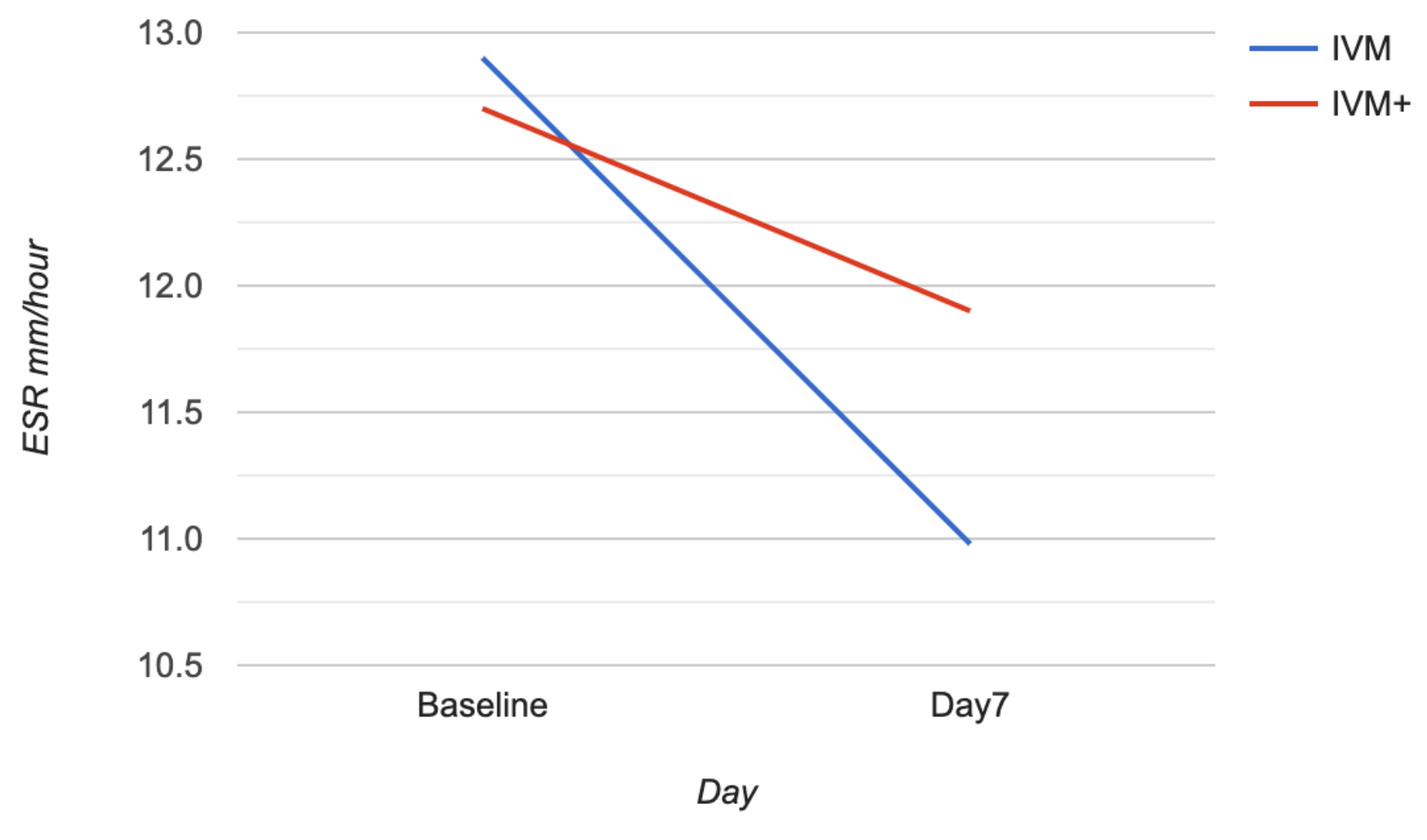

Figure 8

Change in ESR levels from baseline to day $7 \mathrm{P}=0.0025$ 


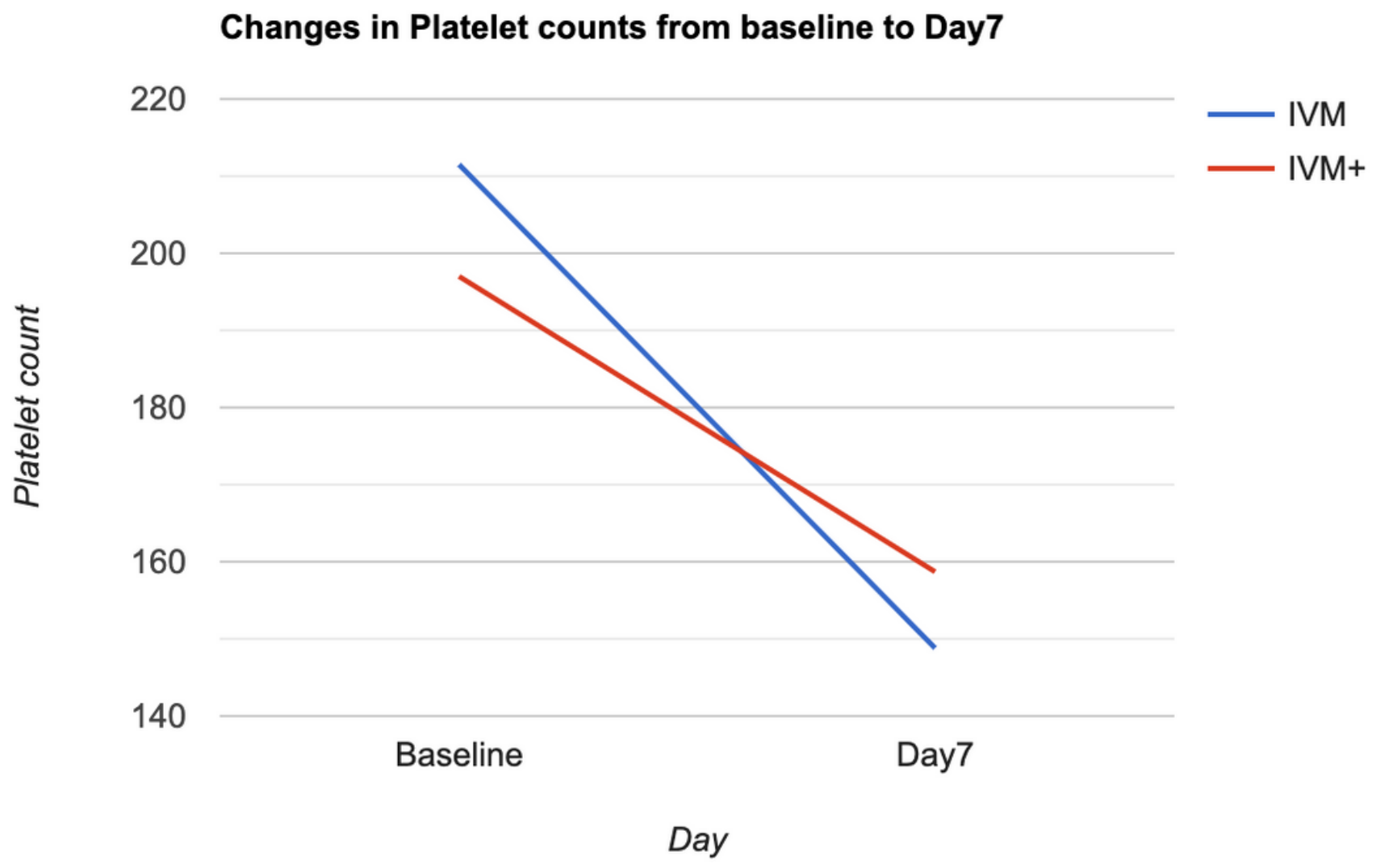

Figure 9

Legend not available with this version of the manuscript. 


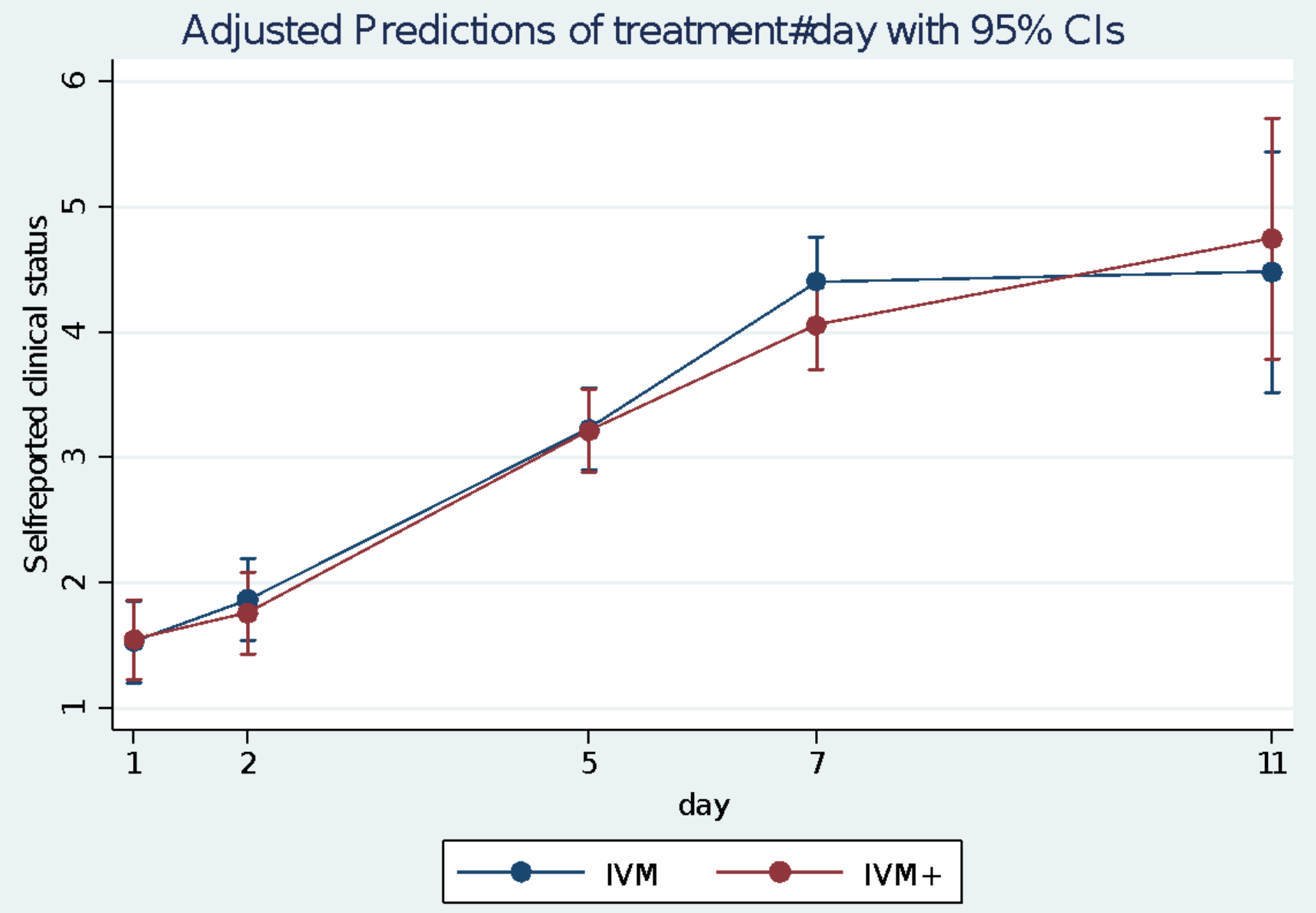

Figure 10

Self-reported clinical status of patients over time using adjusted predictions of treatment-by-day interaction with $95 \%$ confidence interval error bars. 1-much worse/very bad; 5-Much improved/Very good. 


\section{Complaints/?Adverse events}

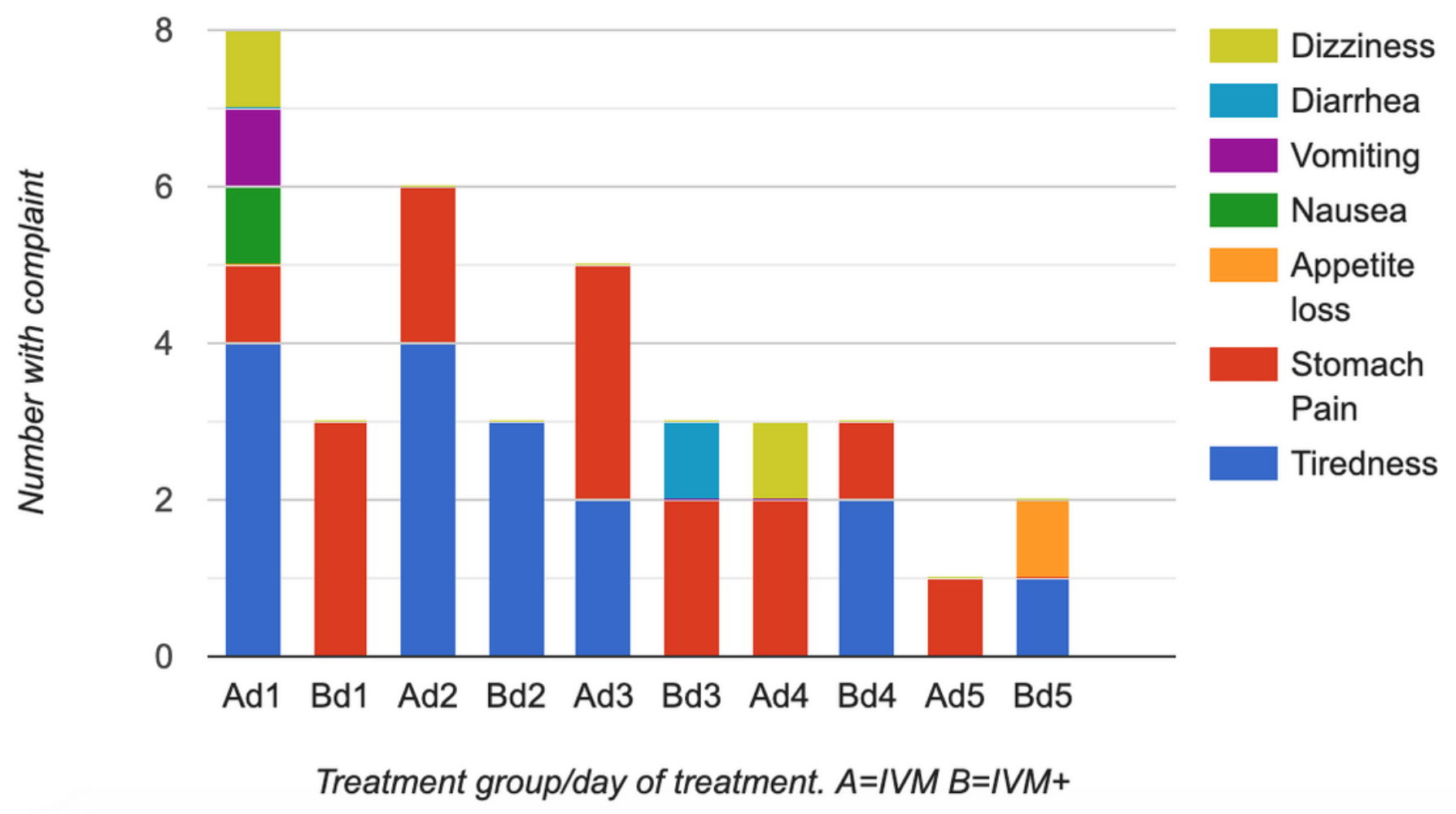

\section{Figure 11}

Occurrence of adverse reactions/main clinical complaints. Key: Ad1 significant complaints on day 1 in IVM group Bd1 significant complaints on day 1 in IVM+ group Ad2 significant complaints on day 2 in IVM group etc.....

\section{Supplementary Files}

This is a list of supplementary files associated with this preprint. Click to download.

- Abujacovidcodes.docx

- Abujacovidredux2.xlsx 